\title{
POLA SEBARAN DAN RISIKO KEJADIAN DEMAM BERDARAH DENGUE DI KECAMATAN MEREK KABUPATEN KARO
}

\author{
Nelson Tanjung \\ Jurusan Kesehatan Lingkungan Poltekkes Kemenkes Medan \\ email : tanjung1763 @gmail.com
}

\begin{abstract}
Dengue Hemorrhagic Fever is still one of the public health problems in the Merek District and tends to show a fluctuating increase. It was reported that in 2017 the total number of DHF cases was 38 cases with a morbidity or Incidence Rate (IR) of 9.4 / 100,000 population, while the case fatality rate (CFR) was 5.3\%. DHF is caused by an imbalance between the three interacting factors, namely host, agent, and environmental factors. The use of Geographic Information System (GIS) is carried out to obtain information about the distribution of cases in each region. The purpose of this study was to determine the distribution patterns and risks that influence the incidence of dengue hemorrhagic fever $(D H F)$ in the Merek District of Karo District. Observational research with a casecontrol design. The case is DHF sufferers. Control is not a sufferer of DHF. Samples were taken by simple random sampling of 62 cases and 62 controls. Where researchers do measurements on the dependent variable beforehand the effect $(D H F)$, while the independent variables are retrospective to determine whether there is a risk of DHF events. The statistical tests used were Chi-Square (bivariate analysis) and Logistic Regression (multivariate analysis). The results of the bivariate analysis showed risk factors for age, education, use of wire mesh and eradication of mosquito nests related to the incidence of DHF. The results of multivariate analysis showed that the risk factor that played a role in the incidence of DHF was the eradication of mosquito nets. The incidence of DHF increases in people who do not have the habit of PSN (Mosquito Nest Eradication) for that practice of cleaning and draining water reservoirs, closures, and burial of used goods.
\end{abstract}

Keyword: DHF, Distribution Pattems, Merek District.

\begin{abstract}
ABSTRAK
Demam Berdarah Dengue masih menjadi salah satu masalah kesehatan masyarakat di Kecamatan Merek, dan cenderung menunjukkan kenaikan yang fluktuatif. Dilaporkan bahwa pada tahun 2017 jumlah seluruh kasus DBD sebanyak 38 kasus dengan angka kesakitan atau Insidance Rate (IR) sebesar 9,4/100.000 penduduk, sedangkan angka kematian atau Case Fatality Rate (CFR) sebesar 5,3 \%. Penyakit DBD disebabkan oleh ketidakkeseimbangan antara tiga faktor yang saling berinteraksi yaitu faktor host, agent, dan lingkungan. Penggunaan Geographic Information System (GIS) dilakukan untuk memperoleh informasi mengenai sebaran kasus di tiap wilayah. Tujuan penelitian ini untuk mengetahui pola sebaran dan risiko yang mempengaruhi kejadian demam berdarah dengue (DBD) di Kecamatan Merek Kabupaten Karo. Penelitian observasional dengan rancangan case control. Kasus adalah penderita DBD. Kontrol adalah bukan penderita DBD. Sampel diambil dengan simple random sampling sebanyak 62 kasus dan 62 kontrol. Dimana peneliti melakukan pengukuran pada variabel dependen terlebih dahulu efek (DBD), sedangkan variabel independen secara retrospektif untuk menentukan ada tidaknya risiko kejadian DBD. Uji statistik yang digunakan adalah Chi-Square (analisis bivariat) dan Logistic Regression (analisis multivariat). Hasill analisis bivariat menunjukkan faktor risiko umur, pendidikan, penggunaan kawat kasa dan pemberantasan sarang nyamuk berhubungan dengan kejadian DBD. Hasil analisis multivariat menunjukkan bahwa faktor resiko yang berperan terhadap kejadian DBD adalah pemberantasan sarang nyamuk. Kejadian DBD meningkat pada orang yang tidak mempunyai kebiasaan PSN (Pemberantasan Sarang Nyamuk) untuk itu praktek pembersihan dan pengurasan tempat penampungan air, penutupan, dan penguburan barang-barang bekas.
\end{abstract}

Kata Kunci: DBD, Pola Sebaran, Kecamatan Merek 


\section{PENDAHULUAN}

\section{Latar Belakang}

Indonesia di klasifikasikan sebagai salah satu negara endemis Demam Berdarah Dengue (DBD) tinggi. Hal ini disebabkan adanya Kejadian Luar Biasa (KLB) DBD yang terjadi secara periodik dalam kurun waktu 3-5 tahun dan kematian akibat dengue banyak terjadi pada anak-anak. Tingginya kasus DBD di Indonesia juga didukung oleh keempat serotype virus Dengue yang bersikulasi di Indonesia dan iklim tropis merupakan faktor pendukung dimana Aedes aegypti sebagai vektor utama dapat hidup dan berkembang biak serta tersebar luas di kota dan desa (WHO, 2009).

Penyakit Demam Berdarah Dengue (DBD) masih merupakan salah satu masalah kesehatan masyarakat yang utama di Indonesia. Pada tahun 2016 terdapat jumlah kasus DBD sebanyak 204.171 kasus dengan jumlah kematian sebanyak 1.598 orang. Jumlah kasus DBD tahun 2016 meningkat dibandingkan jumlah kasus tahun 2015 (129.650 kasus) (Profil Kesehatan Indonesia, 2016)

Berdasarkan beberapa hasil penelitian menyatakan bahwa faktor manusia yang berhubungan dengan kejadian demam berdarah dengue adalah umur, pendidikan, pekerjaan, pengetahuan. Faktor perilaku seperti kebiasaan menggantung pakaian, kebiasaan Pemberantasan Sarang Nyamuk (PSN), menggunakan repelen, bepergian ke daerah endemis, pola tidur. Faktor lingkungan berupa kondisi lingkungan rumah yang tempat penampungan air terbuka, jenis rumah kayu, ventilasi rumah yang tidak menggunakan kasa, kebersihan halaman rumah yang tidak bersih merupakan faktor pendukung terjadinya DBD (Benthem et al., 2004; Sujriyakul et al., 2005).

Perkembangbiakan nyamuk Aedes aegypti dan Aedes alpobictus sebagai vektor DBD sangat dipengaruhi oleh faktor-faktor lingkungan dan kependudukan, antara lain jumlah dan kepadatan penduduk serta kepadatan permukiman. Pertumbuhan penduduk dan pertumbuhan pemukiman yang terus meningkat

dan pengelolaan lingkungan yang belum optimal serta ditunjang oleh kondisi iklim, akan mempercepat persebaran DBD secara meluas.

Kabupaten Karo adalah salah satu wilayah administrasi di Provinsi Sumatera Utara yang setiap tahunnya mengalami peningkatan jumlah penderita DBD, hal ini terlihat dari data Profil Kesehatan Kabupaten Karo. Pada tahun 2011 terdapat 52 kasus DBD yang tersebar di 17 kecamatan dengan kasus tertinggi di kecamatan Barusjahe sebanyak 19 kasus. Pada tahun 2012 meningkat dari tahun sebelumnya menjadi total 78 kasus. $\quad$ Tahun 2013 jumlah kasus meningkat menjadi 82 kasus, dan meningkat tinggi pada tahun 2014 menjadi 248 kasus. Pada tahun 2015 terjadi penurunan jumlah kasus menjadi total 201 kasus, namun pada tahun 2016, jumlah kasus meningkat lagi menjadi 363 kasus DBD. (Dinkes Kabupaten Karo, 2017).

Pada tahun 2017 di Kabupaten Karo Kecamatan Merek dilaporkan bahwa jumlah seluruh kasus DBD sebanyak 38 kasus dengan angka kesakitan atau Insidance Rate (IR) sebesar 9,4/100.000 penduduk, sedangkan angka kematian atau Case Fatality Rate (CFR) sebesar 5,3\%. Bila dibandingkan dengan tahun 2016, maka terdapat penurunan angka kasus DBD yang signifkan, pada tahun 2016 terdapat 363 kasus dengan IR sebesar 91,5/100.000 penduduk. Namun terdapat kenaikan angka kematian (CFR) DBD dari 0 menjadi 5,3\%. (Profil Dinkes Kabupaten Karo, 2017)

Jumlah kasus tertinggi DBD terjadi di Puskesmas Merek yakni sebanyak 28 kasus dengan CFR 7,1\%. Berturut-turut antara lain Puskesmas Kabanjahe sebanyak 5 kasus dengan CFR 0 dan Puskesmas Barusjahe sebanyak 4 kasus dengan CFR 0\%. Pada tahun 2017 kasus DBD hanya terdapat di 4 Puskesmas yaitu Puskesmas Kabanjahe, Merek, Barusjahe dan Kutabuluh, dan 15 puskesmas lainnya tidak terdapat kasus DBD. Sampai saat ini analisis distribusi kasus DBD di Kecamatan Merek masih terbatas hanya dalam bentuk analisis tabular dan grafik. Pada dasarnya upaya surveilans berbasis wilayah guna mengidentifikasi rantai penularan DBD dan identifikasi lokasi penderita sampai alamat lokasi individu sangat dimungkinkan untuk dilakukan, sehingga memperoleh informasi mengenai sebaran kasus di tiap wilayah menggunakan Geographic Information System (GIS).

Melihat berfluktuatifnya kasus DBD di Kecamatan Merek maka perlu dilakukan penelitian untuk mengetahui pola sebaran dan risiko kejadian DBD di Kecamatan Merek Kabupaten Karo.

\section{METODE PENELITIAN}

Penelitian ini dilakukan dilakukan di Kecamatan Merek di Kabupaten Karo pada tahun 2017-2019.

Rancangan penelitian observasional di lapangan, dengan desain case control, dimana peneliti melakukan pengukuran pada variabel dependen terlebih dahulu efek (DBD), sedangkan variabel independen secara retrospektif untuk menentukan ada tidaknya risiko kejadian DBD.

Kasus adalah Penderita DBD yang tertera dalam rekam medis dari Puskesmas Merek Kabupaten Karo Tahun 2016-2017. Kontrol adalah tetangga yang tidak pernah menderita demam berdarah dengue (DBD). 
Jumlah responden untuk kelompok kasus sebanding dengan kelompok control yaitu 1:1 (62:62) yang mana jumlah kelompok kasus adalah penderita Demam Berdarah Dengue dari tahun 2016-2017, sedangkan kelompok control adalah tetangga sekitar kasus yang tidak mengalami DBD Dan pengambilan sampel ini dilakukan dengan simple random sampling atau secara acak sederhana.

Pengumpulan data diperoleh dengan cara pengambilan titik koordinat subyek penelitian menggunakan GPS dan Wawancara untuk memperoleh informasi mengenai resiko kejadian DBD menggunakan kuesioner.

\section{HASIL DAN PEMBAHASAN}

\section{Gambar 1}

Gambaran Umum Kecamatan Merek

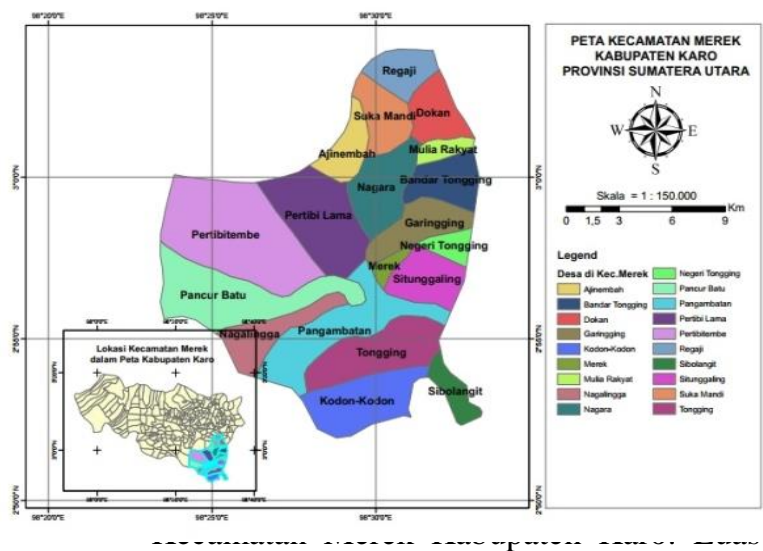

wilayah Kecamatan Merek adalah 125,51 Km2 atau 5,90 persen dari total luas Kabupaten Karo. Seluruh wilayahnya Kecamatan Merek berada pada ketinggian antara 920-1.620 meter di atas permukaan laut. Kecamatan Merek sebagai salah satu Kecamatan di Kabupaten Karo Provinsi Sumatera Utara, terletak 24 km dari kantor Bupati Kabanjahe. Kecamatan ini diapit oleh dua kabupaten dan dua kecamatan, di sebelah utara berbatasan dengan Kecamatan Tigapanah, sebelah selatan berbatasan dengan Kabupaten Dairi, sebelah barat berbatasan dengan Kecamatan Juhar dan sebelah timur berbatas dengan Kabupaten Simalungun. Secara astronomis berada di sekitar $98^{\circ} 25^{\prime}$ Bujur Timur dan $03^{\circ} 12^{\prime}$ Lintang Utara. Jumlah penduduk kecamatan merek sebanyak 20.109 jiwa yang mendiami wilayah seluas $125,51 \mathrm{~km}^{2}$. Sehingga kepadatan penduduk diperkirakan sebesar 267 jiwa/ $/ \mathrm{Km}^{2}$. Laki-laki berjumlah 1.348 jiwa dan perempuan berjumlah 9.761 jiwa. Sex rasionya sebesar 106 Artinya di seperti 100 penduduk perempuan, terdapat 106 penduduk laki-laki. 9.813 atau 95,22 persen bekerja pada lapangan usaha pertanian, sedangkan lapangan pekerjaan lainnya sebanyak 287 orang, PNS/ABRI sebanyak 196 orang. Puskesmas hanya terdapat di ibukota kecamatan yaitu Desa Merek. Puskesmas Pembantu (Pustu) yang merupakan perpanjangan tangan dari
Puskesmas juga masih belum tersebar merata, demikian halnya dengan Poskesdes dan Polindes.

\section{Karakteristik Responden}

Berdasarkan hasil penelitian dilapangan maka didapatkan hasil bahwa responden penelitian jenis kelamin perempuan dan laki-laki sama yaitu $31(50,0 \%)$ responden. Responden yang lebih banyak adalah umur 10-14 tahun sebanyak 16 (25,8\%) responden. Sedangkan paling sedikit adalah umur 3034, umur 55-59 dan umur 60-64 masing-masing 1 $(1,6 \%)$ responden. Subyek dengan kategori pelajar 29 $(46,8 \%)$ responden, paling sedikit pada subjek dengan pekerjaan PNS, buruh dan IRT yaitu 0 $(0,0 \%)$. Desa paling banyak responden terdapat di desa Tongging sebanyak $37(59,7 \%)$ responden, paling sedikit di desa Pancur Batu sebanyak $0(0,0 \%)$.

\section{Kejadian Demam Berdarah Dengue (DBD)}

\section{Gambar 2}

Peta Pola Sebaran Kasus DBD di Kecamatan Merek Kabupaten Karo Tahun 2017-2019.

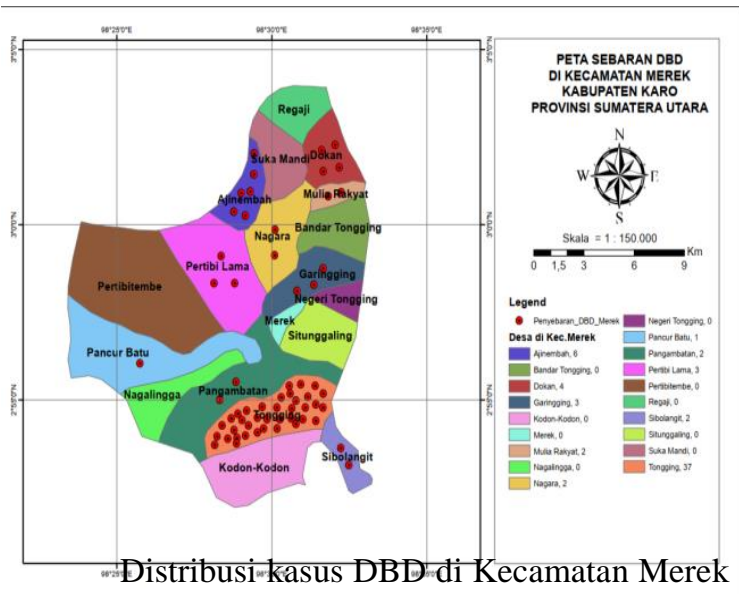

Tahun 2017-2019 tidak merata disemua desa. Berdasarkan hasil penelitian, kasus terbanyak diambil sebagai sampel penelitian adalah di desa Tongging dengan jumlah kasus 37 (29,8\%) responden dan kasus paling sedikit di desa Pancur Batu sebanyak $1(0,8 \%)$ responden.

\section{Analisis Bivariat}

Analisa bivariat dilakukan untuk mengetahui korelasi antara variabel independen

\section{Kejadian DBD dengan umur}

Tabel 1.

Distribusi Kejadian Demam Berdarah Dengue dengan umur di Kecamatan Merek Kabupaten Karo

\begin{tabular}{lcccc}
\hline Variabel & Kasus Kontrol & $\begin{array}{c}\text { Jumla } \\
\text { h }\end{array}$ & $\begin{array}{c}\text { p- } \\
\text { value }\end{array}$ \\
\hline
\end{tabular}




\begin{tabular}{lcccc}
\hline Umur & & & & \\
$<15$ Tahun & 33 & 5 & 38 &, 000 \\
$\geq 15$ Tahun & 29 & 57 & 86 & \\
\hline
\end{tabular}

Dari data pada tabel 1 subyek dengan kategori beresiko umur < 15 tahun sebanyak 38 $(30,6 \%)$ responden dan subyek dengan kategori tidak beresiko umur $\geq 15$ tahun sebanyak $86(69,4 \%)$ responden. Pada kelompok kasus, subyek dengan umur $<15$ tahun sebanyak $33(53,2 \%)$ responden dan subyek dengan kategori tidak beresiko umur $\geq 15$ tahun sebanyak 29(46,8\%) responden. Pada kelompok kontrol, subyek dengan umur $<15$ tahun sebanyak $5(8,1 \%)$ responden dan subyek dengan kategori tidak beresiko umur $\geq 15$ tahun sebanyak $57(91,9 \%)$ responden. Hasil penelitian dengan uji Chi-Square mengenai umur dengan kejadian DBD di Kecamatan Merek menunjukkan bahwa $\mathrm{p}=$ $0,000(\mathrm{p}<0,25)$ sehingga memiliki hubungan bermakna. Hasil penelitian dengan multiple logistic regression mengenai umur dengan kejadian DBD di Kecamatan Merek menunjukkan bahwa $p=$ $0,000(\mathrm{p}<0,05)$ sehingga memiliki hubungan bermakna namun bukan variabel yang paling dominan mempengaruhi kejadian DBD. Menurut hasil penelitian Achmadi (2010) menyatakan bahwa telah terjadi pergeseran kelompok umur yang beresiko terkena DBD dari tahun 1993-2009. Dari Tahun 1993 -1998 kelompok umur terbesar kasus DBD Terjadi pada Kelompok umur < 15 Tahun sedangkan tahun 1999-2009 terjadi pada kelompok umur terbesar kasus DBD cenderung pada kelompok umur $\geq 15$ Tahun. Dan hasil penelitian ini kemungkinan penularan DBD tidak hanya terjadi di rumah tetapi bisa jadi di sekolah atau di tempat kerja. Terjadinya perubahan pola penyakit DBD yang mana dahulu DBD adalah penyakit anak-anak dibawah usia $<15$ tahun dengan asumsi anak-anak lebih banyak melakukan aktivitas di dalam rumah sehingga kontak dengan nyamuk Aedes aegypti lebih besar dari pada orang dewasa atau orang tua yang banyak melakukan aktivoitas di luar rumah. saat ini kejadian DBD telah menyerang seluruh kelompok umur bahkan lebih banyak pada usia produktif. Sehingga gerakan PSN tidak hanya digalakkan dirumah dan sekitarnya saja tetapi bisa di lingkungan sekolah dan di tempat kerja.

\section{Kejadian DBD dengan Pendidikan}

Tabel 2.

Distribusi Kejadian Demam Berdarah Dengue dengan pendidikan di Kecamatan Merek Kabupaten Karo

Variabel Kasu: Kontrol Jumlah p-value

\begin{tabular}{lllll}
\hline Pendidikan & & & & \\
Berisiko & 45 & 31 & 76 &, 017 \\
Tidak & 17 & 31 & 48 & \\
berisiko & & & & \\
\hline
\end{tabular}

Dari data pada tabel 2 subyek dengan tingkat pendidikan berisiko sebanyak $76(61,3 \%)$ respoden dan subyek dengan tingkat pendidikan tidak berisiko sebanyak $48(38,7 \%)$ respoden. Pada kelompok kasus, subyek dengan tingkat pendidikan berisiko sebanyak 45(72,6\%) respoden dan subyek dengan tingkat pendidikan tidak berisiko sebanyak $17(27,4 \%)$ respoden. Pada kelompok kontrol, subyek dengan tingkat pendidikan berisiko sebanyak $31(50,0 \%)$ respoden dan subyek dengan tingkat pendidikan tidak beresiko sebanyak 31(50,0\%) respoden.

Hasil penelitian dengan uji Chi-Square mengenai pendidikan dengan kejadian DBD di Kecamatan Merek menunjukkan bahwa $\mathrm{p}=0,017(\mathrm{p}<0,25) \quad$ sehingga memiliki hubungan bermakna. Hasil penelitian dengan multiple logistic regression mengenai pendidikan dengan kejadian DBD di Kecamatan Merek menunjukkan bahwa $\mathrm{p}=$ $0,017(\mathrm{p}>0,05)$ sehingga tidak dapat dilakukan uji multiple logistic regression. Penelitian Simanullang (2010) tentang faktor risiko kejadian DBD di Kecamatan Wonogiri yang menyatakan bahwa tingkat pendidikan mempunyai hubungan yang bermakna terhadap kejadian DBD (OR 0,53 : CI 95\% 0,19-1,34; p-value 0,144).

Pengetahuan berkaitan erat dengan pendidikan, pendidikan formal dapat mempengaruhi pola pikir dan daya cerna seseorang terhadap informasi yang dapat diterima. Semakin tinggi tingkat pendidikan maka semakin tinggi pula informasi yang dapat diserap sehingga dapat berpengaruh terhadap pengetahuan (Constantianus et al 2006). Berdasarkan hasil penelitian ini, tingkat pendidikan berhubungan dengan kejadian DBD yang jumlah tingkat pendidikan berisiko lebih banyak yaitu $45(72,6 \%)$ responden sedangkan tingkat pendidikan tidak berisiko $17(27,4 \%)$. Hal ini dikarenakan pengetahuan dapat diperoleh tidak hanya berasal dari pendidikan formal saja tetapi juga dapat dari non formal seperti media massa, internet, leaflet/spanduk, petugas kesehatan, dan sebagainya. Roger (1974) dalam notoatmodjo (2003) dalam health belief model menyatakan bahwa model kognitif yang berarti bahwa pengetahuan seseorang dipengaruhi oleh informasi baik secara langsung maupun secara tidak langsung dari health model menyatakan bahwa model kognitif yang berarti bahwa pengetahuan sesorang dipengaruhi oleh informasi baik secara langsung maupun secara tidak langsung dari ligkungan maupun dari hasil belajar.

\section{Berdasarkan Pekerjaan}


Tabel 3

Distribusi Kejadian Demam Berdarah Dengue dengan pekerjaan di Kecamatan Merek Kabupaten Karo

\begin{tabular}{llccc}
\hline Variabel & Kasus & $\begin{array}{c}\text { Ko } \\
\text { ntr } \\
\text { ol }\end{array}$ & $\begin{array}{c}\text { Jumla } \\
\text { h }\end{array}$ & $\begin{array}{c}\text { p- } \\
\text { value }\end{array}$ \\
\hline $\begin{array}{l}\text { Pekerjaan } \\
\text { Berisiko }\end{array}$ & 51 & 46 & 97 &, 384 \\
$\begin{array}{l}\text { Tidak } \\
\text { berisiko }\end{array}$ & 11 & 16 & 27 & \\
\hline
\end{tabular}

Dari data pada tabel 3 subyek dengan pekerjaan kategori berisiko sebanyak 97(78,2\%) responden dan subyek dengan pekerjaan kategori tidak berisiko sebanyak $27(21,8 \%)$ responden. Pada kelompok kasus, subyek dengan pekerjaan kategori berisiko sebanyak $51(82,3 \%)$ responden dan subyek dengan pekerjaan kategori tidak berisiko sebanyak $11(17,7 \%)$ responden. Pada kelompok kontrol, subyek dengan pekerjaan kategori berisiko sebanyak $46(74,2 \%)$ responden dan subyek dengan pekerjaan kategori tidak berisiko sebanyak $16 \quad(25,8 \%)$ responden.

Hasil penelitian dengan uji Chi-Square mengenai pekerjaan dengan kejadian DBD di Kecamatan Merek menunjukkan bahwa $\mathrm{p}=0,384$ $(\mathrm{p}>0,25)$ sehingga tidak memiliki hubungan bermakna. Hasil penelitian dengan multiple logistic regression mengenai pekerjaan dengan kejadian DBD di Kecamatan Merek menunjukkan bahwa $\mathrm{p}=$ $0,384(\mathrm{p}>0,05)$ sehingga tidak dapat dilakukan uji multiple logistic regression. Hubungan pekerjaan dengan penyakit DBD lebih pada aktivitas seseorang atau pekerja di luar rumah, artinya peluang untuk terkena gigitan nyamuk Aedes aegypti baik di rumah maupun di dalam rumah. Hubungan dengan aktivitas seseorang dimana semakin tinggi aktivitas, kondisi tubuh akan mengalami kelelahan, dengan demikian pada kondisi tubuh tidak dalam keadaan sehat atau imunitas menurun maka virus yang ditularkan oleh nyamuk Aedes aegypti dapat dengan mudah menyebabkan sakit.

\section{Berdasarkan Bepergian ke Daerah Endemis} Tabel 4

Distribusi Kejadian Demam Berdarah

Dengue dengan bepergian kedaerah endemis di Kecamatan Merek Kabupaten

\begin{tabular}{lcccc}
\multicolumn{1}{c}{ Variabel } & $\begin{array}{c}\text { Kasu } \\
\text { s }\end{array}$ & $\begin{array}{c}\text { Kon } \\
\text { trol }\end{array}$ & $\begin{array}{c}\text { Juml } \\
\text { ah }\end{array}$ & p-value \\
\hline $\begin{array}{l}\text { Bepergian } \\
\text { ke daerah } \\
\text { endemis }\end{array}$ & & & & \\
$\begin{array}{l}\text { Kedaerah } \\
\text { Endemis }\end{array}$ & 43 & 36 & 79 &, 262 \\
Tidak & 19 & 26 & 45 & \\
\hline
\end{tabular}

kedaerah

endemis

Dari data pada tabel 4 subyek dengan kebiasaan bepergian ke daerah endemis sebanyak $79(63,7 \%)$ responden dan subyek dengan kebiasaan tidak bepergian ke daerah endemis sebanyak 45 (36,3\%) responden. Pada kelompok kasus, subyek dengan kebiasaan bepergian ke daerah endemis sebanyak $43(69,4 \%)$ responden dan subyek dengan kebiasaan tidak bepergian ke daerah endemis sebanyak 19 $(30,6 \%)$ responden. Pada kelompok kontrol, subyek dengan kebiasaan bepergian ke daerah endemis sebanyak 36(58,1\%) responden dan subyek dengan kebiasaan tidak bepergian kedaerah endemis sebanyak 26(41,9\%) responden. Hasil penelitian dengan uji Chi-Square mengenai bepergian kedaerah endemis dengan kejadian DBD di Kecamatan Merek menunjukkan bahwa $\mathrm{p}=0,202(\mathrm{p}<0,25)$ sehingga memiliki hubungan bermakna. Hasil penelitian dengan multiple logistic regression mengenai bepergian kedaerah endemis dengan kejadian DBD di Kecamatan Merek menunjukkan bahwa $\mathrm{p}=$ $0,202(\mathrm{p}<0,05)$ sehingga tidak dapat dilakukan uji multiple logistic regression. Berdasarkan penelitian Wichman et al. dalam Soedarto (2012) menyatakan bahwa 50\% penderita yang menderita dengue berat menunjukan respon imun primer (infeksi dengue pertama kali), dan 30\% dari mereka baru pertama kali mengunjungi daerah endemis dengue.

\section{Berdasarkan Pemberantasan Sarang Nyamuk (PSN)}

Tabel 5.

Distribusi Kejadian Demam Berdarah Dengue dengan kebiasaan PSN di Kecamatan Merek Kabupaten Karo

\begin{tabular}{lcccc}
\hline Variabel & $\begin{array}{c}\text { Kasu } \\
\text { S }\end{array}$ & $\begin{array}{c}\text { Kont } \\
\text { rol }\end{array}$ & $\begin{array}{c}\text { Jumla } \\
\text { h }\end{array}$ & $\begin{array}{c}\text { p- } \\
\text { value }\end{array}$ \\
\hline Kebiasaan & & & & \\
PSN & & & & \\
Ya & 40 & 7 & 47 &, 000 \\
Tidak & 22 & 55 & 77 & \\
\hline
\end{tabular}

Dari data pada tabel 5 subyek dengan PSN sebanyak 47(39,9\%) responden dan subyek dengan tidak memiliki kebiasaan PSN sebanyak 77(62,1\%) responden. Pada kelompok kasus, subyek dengan kebiasaan PSN sebanyak 40(64,5\%) responden dan subyek dengan tidak memiliki kebiasaan PSN sebanyak 22(35,5\%) responden. Pada kelompok kontrol, subyek dengan kebiasaan PSN sebanyak $7(11,3 \%)$ responden dan subyek dengan dengan tidak memiliki kebiasaan PSN sebanyak 55(88,7\%) responden. Hasil penelitian dengan uji Chis Square 
mengenai kebiasaan PSN dengan kejadian DBD di Kecamatan Merek menunjukkan bahwa $p=0,000$ $(\mathrm{p}<0,25)$ sehingga memiliki hubungan bermakna. mengenai kebiasaan PSN dengan kejadian DBD di Kecamatan Merek menunjukkan bahwa $\mathrm{p}=0,000$ $(\mathrm{p}<0,05)$ sehingga dapat dilakukan uji multiple logistic regression dan memiliki hubungan bermakna serta merupakan variabel yang paling dominan mempengaruhi kejadian DBD.

Penelitian Widiyanto (2007) tentang kajian manajemen lingkungan terhadap kejadian DBD di Kecamatan Merek yang menyatakan bahwa partisipasi masyarakat dalam PSN tidak mempunyai hubungan yang bemakna terhadap kejadian DBD (pvalue 0,152 ). Meningkatnya kasus DBD dari tahun ke Tahun kemungkinan disebabkan kurangnya partisipasi masyarakat dalam kegiatan PSN selain kurang efektifnya insektisida digunakan dalam program pengendalin Vektor secara pengasapan atau thermal fogging. Kebiasaan PSN terdiri dari praktek pembersihan dan pengurasan tempat penampungan air, penutupan, dan penguburan barang-barang bekas. kebiasaan penduduk menyimpan air di tempat penampungan air (TPA) untuk keperluan hidup manusia seperti drum, tempayan, bak mandi dan ember akan menjadi tempat perkembangbiakan nyamuk aides aegepty (soegijanto,2006). Menurut green at al., (1980) menyatakan bahwa satu perilaku dala pelaksanaan pembersihan sarag nyamuk, ditentukan dalam 3 faktor: faktor predisposisi/faktor yang berasal dari dalam individu sendiri (pendidikan, pekerjaan, pendapatan, dan pengetahuan), faktor enabling/faktor yang memungkin kan (manajemen dan tenaga kesehatan). dan faktor reinforcing/faktor penguat (keluarga dan masyarakat sekitar). Salah satu upaya pengendalian terhadap nyamuk aedes aegypti adalah dengan melakukan kegiatan PSN. Penelitian ini sesuai dengan hasil penelitian yang dilakukan oleh Fathi and Chatarina (2005) yang menyatakan bahwa dengan melakukan kegiatan PSN dapat menurunkan angka kejadian DBD

\section{Berdasarkan Penggunaan Kawat Kasa}

Tabel 6.

Distribusi Kejadian Demam Berdarah Dengue dengan Penggunaan Kawat Kasa di Kecamatan Merek Kabupaten Karo

\begin{tabular}{lcccc}
\hline Variabel & Kasus & $\begin{array}{c}\text { Kont } \\
\text { rol }\end{array}$ & $\begin{array}{c}\text { Juml } \\
\text { ah }\end{array}$ & $\begin{array}{c}\text { p- } \\
\text { value }\end{array}$ \\
\hline Penggunaan & & & & \\
Kawat Kasa & & & & \\
Tidak & 46 & 27 & 73 &, 001 \\
Ya & 16 & 35 & 51 & \\
\hline
\end{tabular}

Dari data pada tabel 6 subyek dengan menggunakan kawat kasa sebanyak 51(41,1\%) responden dan subyek dengan tidak menggunakan kawat kasa sebanyak 73(58,9\%) responden. Pada kelompok kasus, subyek dengan menggunakan kawat kasa sebanyak $16(25,8 \%)$ responden dan subyek dengan tidak menggunakan kawat kasa sebanyak 46(74,2\%) responden. Pada kelompok kontrol, subyek dengan menggunakan kawat kasa sebanyak 35(56,5\%) responden dan subyek dengan dengan tidak menggunakan kawat kasa sebanyak 27(43,5\%) responden. Hasil penelitian dengan uji Chis Square mengenai penggunaan kawat kasa dengan kejadian DBD di Kecamatan Merek menunjukkan bahwa $\mathrm{p}=$ $0,001 \quad(\mathrm{p}<0,25)$ sehingga memiliki hubungan bermakna. mengenai penggunaan kawat kasa dengan kejadian DBD di Kecamatan Merek menunjukkan bahwa $\mathrm{p}=0,001(\mathrm{p}<0,05)$ sehingga dapat dilakukan uji multiple logistic regression dan memiliki hubungan bermakna tetapi bukan merupakan variabel yang paling dominan mempengaruhi kejadian DBD.

Penelitian yang dilakukan Maria (2013) menyatakan bahwa terdapat hubungan antara penggunaan kasa pada ventilasi dengan kejadian DBD. Hasil penelitian tersebut memperkuat penelitian ini bahwa penggunaan kasa berhubungan dengan kejadian DBD. Penggunaan kawat kasa pada ventilasi cukup penting untuk mencegah nyamuk masuk kedalam rumah, namun masih jarang responden yang memasang kawat kasa pada ventilasinya. Kurangnya penggunaan kawat kasa pada ventilasi di sebabkan responden yang belum mengetahui manfaat dari penggunaan kawat kasa. Ketidaktahuan tersebut menyebabkan responden menganggap bahwa penggunaan kasa pada ventilasi kurang penting. Adapula responden yang memberikan alasan tidak memasang kawat kasa karna harga kawat kasa yang mahal, sehingga tidak mampu membeli. Rumah dengan kondisi ventilasi yang tidak menggunakan kawat kasa akan memudahkan nyamuk untuk masuk kedalam rumah dan menggigit manusia serta meletakan telurnya di kontainer. Dengan dipasangkanya kawat kasa pada ventilasi maka kemungkinan nyamuk untuk masuk kerumah dan menggigit manusia dapat dicegah sehingga resiko terkena penyakit DBD semakin kecil. Sangat jarang ditemukan rumah warga yang memasang kawat kasa pada ventilasinya. Kurangnya contoh rumah warga yang memasang kawat kasa serta tidak adanya budaya memasang kawat kasa pada ventilasi membuat warga lain tidak tertarik untuk memasangnya

Hasil penelitian tersebut menunjukan bahwa penggunan kawat kasa pada ventilasi berhubunan dengan kejadian DBD di Kecamatan Merek. Keberadaan kawat kasa memiliki hubungan dengan kejadian DBD karna sebagian besar responden tidak memasang kawat kasa pada ventilasi rumahnya. Penggunaan kawat kasa yang kurang dikarenakan 
masyarakat tidak mengetahui manfaat dari memasang kawat kasa serta tidak ada trend memasang kawat kasa pada ventilasi. Masyarakat cenderung suka mengikuti trend. Memasang kawat kasa merupakan salah satu upaya pencegahan terjadinya penularan penyakit DBD (Kemenkes RI, 2005). Menurut dari penelitian Berdian (2013) menunjukan juga adanya hubungan antara penggunaan kasa pada ventilasi dengan kejadian DBD di Kelurahan Perumnas Way Halim Kota Bandar Lampung. Penelitian tersebut juga sejalan dengan hasil penelitian ini. Ventilasi adalah lubang tepat udara keluar masuk secara bebas. Ventilasi juga digunakan nyamuk untuk tempat perpindahan keluar maupun masuk kedalam rumah. Nyamuk berpindah tempat memasuki rumah selain memasuki pintu, juga melewati ventilasi rumah. Kawat kasa merupakan susunan kawat dengan lubang pori yang kecil. Lubang pori yang kecil ini membuat nyamuk tidak bisa melewatinya sehingga nyamuk tidak dapat masuk kedalam rumah.

\section{Berdasarkan Indeks Jarak}

Tabel 7.

Distribusi Kejadian Demam Berdarah Dengue dengan Indeks Jarak di Kecamatan Merek Kabupaten Karo

\begin{tabular}{lllll}
\hline Variabel & $\begin{array}{c}\text { Kasu } \\
\text { s }\end{array}$ & $\begin{array}{c}\text { Kont } \\
\text { rol }\end{array}$ & $\begin{array}{c}\text { Jumla } \\
\text { h }\end{array}$ & $\begin{array}{c}\text { p- } \\
\text { value }\end{array}$ \\
\hline Indeks & & & & \\
Jarak & & & & \\
$\quad$ Dekat & 55 & 55 & 110 & 1,00 \\
$\quad$ Jauh & 7 & 7 & 14 & \\
\hline
\end{tabular}

Dari hasil Tabel 7 subyek dengan indeks jarak kategori dekat sebanyak $110(88,7 \%)$ responden dan subyek dengan indeks jarak kategori jauh sebanyak 14(11,3\%) responden. Pada kelompok kasus, subyek dengan indeks jarak kategori dekat sebanyak $55(88,7 \%)$ responden dan subyek dengan indeks jarak kategori jauh sebanyak 7(11,3\%) responden. Pada kelompok kontrol, subyek dengan indeks jarak kategori dekat sebanyak 55(88,7\%) responden dan subyek dengan dengan indeks jarak kategori jauh sebanyak 7(11,3\%) responden. Hasil penelitian dengan uji Chis Square mengenai penggunaan kawat kasa dengan kejadian DBD di Kecamatan Merek menunjukkan bahwa $\mathrm{p}=0,001(\mathrm{p}<0,25)$ sehingga tidak memiliki hubungan bermakna. mengenai indeks jarak dengan kejadian DBD di Kecamatan Merek menunjukkan bahwa $\mathrm{p}=1,000 \quad(\mathrm{p}>0,05)$ sehingga tidak dapat dilakukan uji multiple logistic regression. Jarak antar rumah warga semuanya berjarak $\leq 100 \mathrm{~m}$. Jarak antar rumah warga memang tergolong dekat. Terdapat juga rumah yang dempet tidak ada jarak antar rumah di sampingnya. Hasil penelitian mengenai jarak antar rumah dengan kejadian DBD menunjukkan bahwa seluruh rumah responden jarak antar rumahnya $\leq 100 \mathrm{~m}$. Jarak terbang nyamuk Aedes aegypti adalah $100 \mathrm{~m}$ (Kementerian Kesehatan RI, 2004). Jika jarak antar rumah $\leq 100 \mathrm{~m}$, maka nyamuk Aedes aegypti mampu untuk menjangkaunya sehingga penularan penyakit DBD dapat dengan mudah untuk menyebar sehingga perlu pemasangan kasa pada ventilasi. Kebanyakan rumah responden berjarak antara $<50$ meter. Bahkan terdapat pula yang dempet. Biasanya, jarak antar rumah digunakan untuk jalan menuju rumah bagian belakang atau tempat untuk memarkir sepeda motor. Jarak antar rumah juga digunakan warga sebagai penyimpanan barang-barang yang tidak terpakai, seperti kayu.

Jarak antar rumah dipengaruhi oleh luas tanah dari tempat tinggal masyarakat. Jika mempunyai tanah yang cukup luas, maka terdapat jarak antar rumah. Namun jika luas tanah yang dimiliki tidak begitu besar, maka setiap rumah tidak mempunyai jarak atau dapat dikatakan dempet. Pada masyarakat Kecamatan Merek, jarak antar rumah menjadi cukup penting. Jarak antar rumah digunakan sebagai jalan ataupun tempat penyimpanan barangbarang tidak terpakai. Tempat seperti ini sangat rentan sebagai tempat persembunyian nyamuk Aedes aegypti. Nyamuk Aedes aegypti senang bersembunyi di tempat yang gelap dan lembab. Maka tidak heran jika saat peneliti masuk ke dalam lompongan, banyak ditemui nyamuk yang beterbangan. Jika ventilasi rumah tidak diberi kasa, maka memudahkan nyamuk untuk masuk ke dalam rumah. Keadaan jarak antar rumah yang dekat dapat memudahkan berpindahnya nyamuk dari satu rumah ke rumah yang lain. Jika jarak antar rumah berjauhan atau > $100 \mathrm{~m}$, maka nyamuk sulit untuk menjangkaunya. Jarak antar rumah cukup penting dalam kehidupan bertetangga. Jarak antar rumah yang berdempetan juga dapat menimbulkan masalah. Diantaranya masalah rembesan air yang dialami oleh salah seorang responden. Rembesan air pada tembok akan menyebabkan hawa dalam rumah menjadi lembab. Lembabnya udara di dalam rumah selain menimbulkan tumbuhnya jamur, juga menjadi sarang yang nyaman bagi nyamuk Aedes aegypti. Jarak antar rumah juga dapat menimbulkan masalah pencahayaan dan sirkulasi udara. Dengan tembok yang dempet, maka jumlah jendela akan semakin sedikit. Hawa di dalam rumah pun juga akan terpengaruh, yaitu menjadi lembab dan kurang terkena sinar matahari karena kurangnya sirkulasi udara di dalam rumah. Nyamuk Aedes aegypti senang di tempat tempat yang lembab dan gelap (Yudhastuti, 2011).

\section{KESIMPULAN DAN SARAN}

Terdapat hubungan antara umur dengan kejadian DBD di Kecamatan Merek. Terdapat hubungan antara pendidikan dengan kejadian DBD di Kecamatan Merek. Terdapat hubungan antara kebiasaan PSN dengan kejadian DBD di Kecamatan 
Merek Terdapat hubungan antara penggunaan kawat kasa dengan kejadian DBD di Kecamatan Merek.Variabel kebiasaan PSN yang paling dominan berhubungan dengan kejadian DBD di wilayah kecamatan Merek dengan Exp B 11,468 (p-value $, 000,95 \%$ CI 4,155-31,650).Dari kejadian yang ditemukan di lapangan sebaiknya pihak instansi puskesmas Merek dan Dinas kesehatan Karo lebih mampu meningkatkan kembali sistem surveilens DBD berbasis masyarakat dan pengamatan vektor terutama pada daerah pemukiman padat penduduk. pemberdayaan masyarakat sangat diperlukan atau disarankan khususnya dalam upaya pengendalian vektor DBD yang berkesinambungan. Diharapkan masyarakat untuk lebih memperhatikan $3 \mathrm{M}$ plus dan pelaksanaan PSN DBD secara mandiri dan teratur. Hasil penelitian ini dapat diteruskan oleh peneliti lain dengan menambah jumlah variabel dan jumlah sampel penelitian sehingga diharapkan dapat memperkuat keputusan yang akan diambil.

\section{DAFTAR PUSTAKA}

Achmadi, U.F. (2010) Buletin Jendela Epidemiologi. Pusat Data dan Surveilans Epidemiologi Kementerian Kesehatan RI

Berdian, R. 2013. Hubungan Faktor Lingkungan, dan Perilaku dengan Kejadian Demam Berdarah Dengue di Wilayah Kelurahan Way Halim Kota Bandar Lampung. Skripsi. Universitas Diponegoro, Semarang, Indonesia.

Dardjito, E, Yuniarno, S, Wibowo, C, Saprasetya, A \& Dwiyanti, H (2008) Beberapa Faktor Risiko Yang Berpengaruh Terhadap Kejadian Penyakit Demam Berdarah Dengue (DBD) di Kabupaten Banyumas. Media Litbang Kesehatan, XVIII.

Fathi, S.K \& Catharina, U.W. (2005) Peran Faktor Lingkungan dan Perilaku terhadap Penularan Demam Berdarah Dengue, Malang: Universitas Muhammadiyah Malang.

Green, L.W., Kreuter, M.W., Deeds, S.S \& Partidge, K.B. (1980) Health Education Planning, A Diagnostic Approach The John Hopkins University USA: Mayfields Publishing Company.

Kementerian Kesehatan RI. 2004. Modul Surveilans. Jakarta. Direktorat Jenderal Pengendalian Penyakit dan Penyehatan Lingkungan.

Kementerian Kesehatan RI. 2005. Pencegahan dan Pemberantasan Demam Berdarah Dengue di Indonesia. Jakarta. Direktorat Jenderal Pengendalian Penyakit dan Penyehatan Lingkungan.
Maria, I. 2013. Faktor Risiko Kejadian Demam Berdarah Dengue di Kota Makassar tahun 2013. Skripsi. Universitas Hassanudin, Makassar, Indonesia.

Notoadmodjo, S. (2003) Pendidikan dan Perilaku Kesehatan, Jakarta: Rineka Cipta.

Simanullang, P.M. (2010) Faktor-Faktor Risiko Kejadian Demam Berdarah Dengue (DBD) Dan Pemetaan Resistensi Nyamuk Aedes Aegypti di Kecamatan Wonogiri Kabupaten Wonogiri Tahun 2010. Fakultas Kedokteran, Pascasarjana, Universitas Gadjah Mada.

Soedarto (2012) Demam Berdarah Dengue, Jakarta: Sagung Seto.

Soegijanto, S. (2006) Demam Berdarah Dengue, Surabaya: Airlangga University Press.

Widiyanto, T. (2007) Kajian Manajemen Lingkungan Terhadap Kejadian Demam Berdarah Dengue (DBD) di Kota Purwokerto Jawa Tengah. Pascasarjana, Universitas Diponegoro.

Yudhastuti, R. 2011. Pengendalian Vektor dan Rodent. Surabaya. Pustaka Melati. 